\section{Obesity and recurrent vulvovaginal bacterial infections in women of reproductive age}

Obesity, defined as an excessive deposition of body fat, and usually reported as body mass index (BMI) exceeding $30 \mathrm{~kg} / \mathrm{m}^{2}$, has been linked to increased morbidity and mortality and has been associated with an increased risk of cancer, cardiovascular diseases, Type II diabetes (DM) and infections. ${ }^{1-5}$ Obesity is a low-grade inflammatory state, ${ }^{67}$ and adipose tissue is an active immunological organ with increased production of tumour necrosis factor $\alpha$, interleukin (IL)-1 $\beta$ and IL- $6 .{ }^{8}$ Obesity is associated with an increased susceptibility to infections; however, the results of clinical studies evaluating BMI and vaginitis are controversial. ${ }^{9}$ The aim of the discussed study was to determine the association between obesity and recurrent vulvovaginal bacterial infections (RVVBI) in women of reproductive age.

This study was conducted at the gynaecology clinics at Texas Tech University Health Sciences Center at the Permian Basin between April 2013 and December 2015. The TTUHSC Institutional Review Board approved the study that is part of a database collection registered at ClinicalTrials.gov.

Non-pregnant patients (age range 18-40 years old) with a history of RVVBI, as defined by the International Society for the Study of Vulvovaginal Disease were included in this study $(\mathrm{n}=55)$, as well as age-matched controls $(\mathrm{n}=50)$. Patients' BMI at the clinic visit was recorded. Additionally, vaginal swabs were analysed using quantitative PCR as described by us previously. ${ }^{10}$ The following bacterial species were included: Gardnerella vaginalis, Atopobium vaginae, Megasphaera type I, Megasphaera type II, bacterial vaginosis-associated bacterium 2, Ureaplasma urealiticum and Mycoplasma genitalis. Lactobacilli were discerned using qPCR assay that identified $L$. jensenii, L. crispatus and L. gasseri. ${ }^{11}{ }^{12}$ Statistical analysis was performed with GraphPad software (La Jolla, California, USA). Categorical data were analysed with $\chi^{2}$ two sites, Student's t-test was used for differences in continuous variables. A multivariate logistic regression model (with backward elimination) was made to identify independent risk factors associated with RVVBI. ORs and their 95\% CIs were calculated, and $\mathrm{p}<0.05$ was considered to be significant.

The BMI in the group of patients with RVVBI was $35 \pm 4 \mathrm{~kg} / \mathrm{m}^{2}$ vs $26 \pm 3 \mathrm{~kg} / \mathrm{m}^{2}$ in the control group $(\mathrm{p}<0.001)$. Multivariate logistic regression analysis indicated that higher BMI was associated with RVVBI (OR 4.00, 95\% CI 3.1 to 4.52$)(\mathrm{p}=0.001)$. Obesity was also associated with the presence of $L$. iners and IL-1ro, IL-6, IL-12 and IL-17 ( $p=0.01$ to $p=0.001)$.

The pathophysiology behind obesitydriven, increased susceptibility to infectious diseases is not well understood.

The leading bacteria in the vaginal milieu in humans are Lactobacilli. ${ }^{10}$ They hold antimicrobial properties that control the vaginal milieu and the urogenital microbiota. L. iners, first described by Antonio, has been associated with both: normal vaginal milieu and vagina colonised by species of bacterial vaginosis ${ }^{6}$; our data are in agreement with this observation.

The present study is the first to describe the association between BMI and RVVBI. This study has several limitations including the retrospective design, absence of information regarding patients' ethnicity, sexual history and DM.

Based on the evidence obtained in this study, obesity might be an independent risk factor for RVVBI in women of reproductive age through the mechanism of altered vaginal immunity.

This research was done with the assistance of the Clinical Research Institute at TTUHSC, particularly that of Mrs Cathy Lovett and Mrs Ailena Mulkey, who both assisted with patient recruitment and handling specimens.

\section{Gary Ventolini, ${ }^{1}$ Nuvneet Khandelwal, ${ }^{1}$ Kathryn Hutton, ${ }^{1}$ Jonathan Lugo, ${ }^{1}$ Scott E Gygax, ${ }^{2}$ Natalia Schlabritz-Loutsevitch}

'Department of Obstetrics and Gynecology, Texas Tech University Health Sciences Center at the Permian Basin, Odessa, Texas, USA

${ }^{2}$ Genesis Biotechnology Group, Femeris Women's Health Research Center, Hamilton, New Jersey, USA

Correspondence to Dr Gary Ventolini, Texas Tech University Health Sciences Center at the Permian Basin, School of Medicine, 800 West 4th Street, Odessa,

TX 79763, USA; gary.ventolini@ttuhsc.edu

Correction notice This article has been corrected since it was published Online First. Correction has been made in the 'Contributors' footnote.

Contributors GV had the idea for the article and is the guarantor. NK performed the literature search and wrote the manuscript. $\mathrm{KH}$ and JL performed data collection and approved the final version of the manuscript. SEG performed experimental work and approved the final version of the manuscript. NS-L performed experimental work, performed literature search, wrote the manuscript and approved the final version of the manuscript.

Competing interests None declared.

Patient consent Obtained.

Ethics approval Texas Tech University Health Sciences Center Institutional Review Board.
Provenance and peer review Not commissioned; internally peer reviewed.

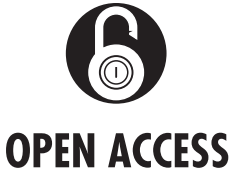

Open Access This is an Open Access article distributed in accordance with the Creative Commons Attribution Non Commercial (CC BY-NC 4.0) license, which permits others to distribute, remix, adapt, build upon this work non-commercially, and license their derivative works on different terms, provided the original work is properly cited and the use is non-commercial. See: http:/l creativecommons. org/licenses/by-n/4.0/

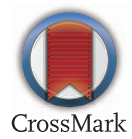

To cite Ventolini G, Khandelwal N, Hutton K, et al. Postgrad Med J 2017;93:297.

Published Online First 23 January 2017

Postgrad Med J 2017;93:297.

doi:10.1136/postgradmedj-2016-134638

\section{REFERENCES}

1 Cooney, KA, Gruber SA. Hyperglycemia, obesity, and cancer risks on the horizon. JAMA 2005;293:235-6.

2 Nguyen NT, Magno CP, Lane KT, et al. Association of hypertension, diabetes, dyslipidemia, and metabolic syndrome with obesity: findings from the National Health and Nutrition Examination Survey, 1999 to 2004. J Am Coll Surg 2008;207:928-34.

3 Hainer V, Zamrazilová $H$, Kunešová $M$, et al. Obesity and infection: reciprocal causality. Physiol Res 2015;64(Suppl 2):S105-19

4 Stevens J, Erber E, Truesdale KP, et al. Long- and short-term weight change and incident coronary heart disease and ischemic stroke: the Atherosclerosis Risk in Communities Study. Am J Epidemiol 2013;178:239-48

5 Mokdad AH, Ford ES, Bowman BA, et al Prevalence of obesity, diabetes, and obesity-related health risk factors, 2001. JAMA 2003:289:76-9.

6 Del Cornò M, D'Archivio M, Conti L, et al. Visceral fat adipocytes from obese and colorectal cancer subjects exhibit distinct secretory and $\omega 6$ polyunsaturated fatty acid profiles and deliver immunosuppressive signals to innate immunity cells. Oncotarget 2016;7:63093-105.

7 Grant, RW, Dixit VD. Adipose tissue as an immunological organ. Obesity (Silver Spring) 2015;23:512-18.

8 Mastrobattista JM, Klebanoff MA, Carey JC, et al. The effect of body mass index on therapeutic response to bacterial vaginosis in pregnancy. $A m$ J Perinatol 2008;25:233-7.

9 Schlabritz-Loutsevitch N, Gygax S, Dick E, et al. Vaginal dysbiosis from an evolutionary perspective. Sci Rep 2016;6:26817.

10 Balashov SV, Mordechai E, Adelson ME, et al. Multiplex quantitative polymerase chain reaction assay for the identification and quantitation of major vaginal lactobacilli. Diagn Microbiol Infect Dis 2014:78:321-7.

11 Antonio MA, Hawes SE, Hillier SL. The identification of vaginal Lactobacillus species and the demographic and microbiologic characteristics of women colonized by these species. J Infect Dis 1999;180:1950-6. 